EDUARDO LUIZ DE SOUSA SOARES

\title{
A POLÍTICA EXTERNA INDEPENDENTE \\ E A RELAÇÃO BRASIL-ÁFRICA
}

Trabalho de Conclusão de Curso de Relações Internacionais para a Universidade de Brasília, apresentado como requisito parcial à obtenção do título de Especialista em Relações Internacionais 
EDUARDO LUIZ DE SOUSA SOARES

\section{A POLÍTICA EXTERNA INDEPENDENTE E A RELAÇÃO BRASIL-ÁFRICA}

Trabalho de Conclusão de Curso de Relações Internacionais para a

Universidade de Brasília, apresentado como requisito parcial à obtenção do título de Especialista em Relações Internacionais

Orientador:

Prof. Dr. José Flávio Sombra Saraiva 


\section{FICHA CATALOGRÁFICA}

Soares, Eduardo Luiz de Sousa
A Política Externa Independente e a Relação Brasil-África/
Eduardo Luiz de Sousa Soares; Orientador:
Prof. Dr. José Flávio Sombra Saraiva. - Brasília, 2009
40p.
Trabalho de Conclusão de Curso. Instituto de
Relações Internacionais / Universidade de Brasília.
Curso de Especialização em Relações Internacionais.
1.A Política Externa Independente. 2. Descolonização Africana.
3. A Política Externa Independente aplicada à África.
Instituto de Relações Internacionais




\section{RESUMO}

O objetivo deste estudo é analisar o que foi a Política Externa Independente e a relação do Brasil com a África durante essa política. Faz-se uma análise histórica sobre o período, visando analisar as relações entre o Brasil e o mundo, a África e o mundo, e o Brasil e a África. 


\begin{abstract}
This study analyzes the Brazil's Independent Foreign Policy and the relation of Brazil with the Africa in this policy. It does an historic analyze about this period, looking about the relations between Brazil and the world, Africa and the world, and Brazil and Africa.
\end{abstract}




\section{SUMÁRIO}

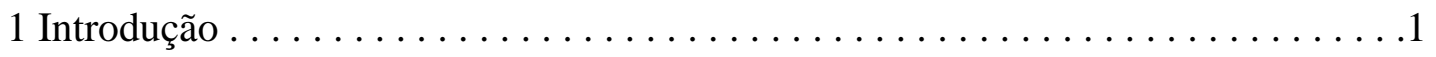

2 Capítulo I - Política Externa Independente. . . . . . . . . . . . . . . 3

3 Capítulo II - Descolonização Africana. . . . . . . . . . . . . . . . . . . . 15

4 Capítulo III - Política Externa Independente Aplicada à África. . . . . . . . . . . .27

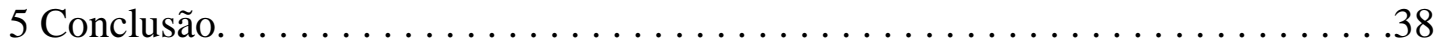

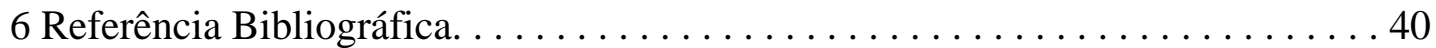




\section{INTRODUÇÃO}

Essa monografia foi feita com o intento de estudar as relações do Brasil com a África dentro da Política Externa Independente. Esta foi uma política externa realizada pelos governos brasileiros dos anos de 1961 à 1964 e teve aplicação em todas as regiões do globo.

A região que nos interessa é a África, por isso estudaremos as políticas dos governos brasileiros para esse continente tanto nos anos da PEI como na história do Brasil. Traçaremos, também, em linhas gerais, a história das relações que aquele continente teve com o mundo.

O empenho do autor deste trabalho foi devido tanto ao gosto pessoal pelo continente quanto à importância que dá à presença africana na história, na política externa e no imaginário presente do Brasil.

O objetivo geral desse trabalho é estudar a importância que a África teve na política brasileira, principalmente durante a Política Externa Independente, quando o continente ganhou destaque especial para o Brasil.

Também é pretendido se mostrar os pormenores desse destaque, enfatizando a visão dos governantes brasileiros e a percepção que possuíam sobre o continente, e as transformações na conjuntura internacional que possibilitaram a mudança de paradigmas na política externa do país com a África.

Para tanto foram utilizados fontes secundárias, constituindo se de livros de especialistas, teses de doutorado e dissertações de mestrado. Não foram utilizadas fontes primárias devido à dificuldade dessa pesquisa e o pouco tempo para realizá-la.

A monografia foi dividida em três capítulos. O capítulo I trata da Política Externa Independente como um todo. Foram analisadas sua concepção, suas propostas, suas políticas e sua aplicação. Foram mostradas, em linhas gerais, suas políticas para todas as regiões onde foram aplicadas.

No capítulo II, foram analisadas a descolonização africana, suas causas, sua história, seus efeitos sobre a África e sobre o mundo. A escolha por esse tópico decorreu das conseqüências que ela teve sobre as relações dos governos brasileiros com o continente e das mudanças que ocorreram a partir dela. 
O capítulo III foca a aplicação da PEI no continente africano. Foram estudados seus pormenores, seus paradigmas, mudanças e continuidades da PEI em relação às políticas anteriores e os detalhes da relação Brasil-África.

Vários autores contribuíram para esse estudo, em destaque as teses de Sibeck, Storrs, Selcher, Vizentini, Aragón e Nunes no primeiro capítulo. Também elas contribuíram para o terceiro capítulo. No segundo, foi de especial ajuda as teses de Pio Penna Filho e Creomar Lima Carvalho de Souza. O livro de Saraiva deve ser enfatizado, pois contribuiu no desenvolvimento de todo o trabalho.

Com este estudo se espera ajudar na compreensão das relações do Brasil com a África e também no conhecimento da Política Externa Independente e da descolonização africana. Será de grande valor para o autor se esta monografia puder auxiliar o estudo de quem for penetrar nesses assuntos. 


\section{CAPÍTULO I - \\ POLÍTICA EXTERNA INDEPENDENTE}

Neste primeiro capítulo, analisaremos a Política Externa Independente, em suas linhas gerais. Nos capítulos seguintes, aprofundaremos sua relação com a África.

Política Externa Independente (PEI) é o nome como foi chamada a política exterior dos governos de Jânio Quadros e de João Goulart. Foi um período de novas experiências no qual a diplomacia se afastou dos tradicionais “aliados” e se aproximou de países antes pouco visados pelo corpo diplomático, são eles o bloco soviético da Europa Oriental, a África sub-saariana, paises asiáticos e vários latino americanos.

A política exterior brasileira historicamente seguia a liderança dos Estados Unidos. Houve algumas ações anteriores da diplomacia brasileira que eram de certa forma independentes como a política externa de Getúlio Vargas com relação à Guerra da Coréia e as ações do Brasil na Liga das Nações. Porém, somente com a PEI o país se virou contra os Estados Unidos.

A PEI pode ser considerada uma política inovadora, ainda que ambígua, principalmente em face da política doméstica conservadora de Quadros. A diplomacia manteve suas metas tradicionais, mas mudou sua direção, passou ao afastamento de antigos países amigos como os Estados Unidos e a Grã-Bretanha, se aproximou dos paises latino americanos e africanos e abriu relações com o bloco soviético.

Historiadores como José Honório Rodrigues argumentam que as bases da PEI datam do século XIX quando o Brasil refutava uma maior influência das nações européias.

As bases históricas da PEI remetem ao primeiro governo Vargas. A diplomacia deste governo ora tomava rumo ao governo de Washington, ora se direcionava à Alemanha nazista com o objetivo de conseguir ajuda econômicomilitar. 
O período que antecede a PEI pode ser caracterizado como oscilante em relação à aproximação com os EUA ${ }^{1}$. Logo após esse período Dutra estabeleceu uma política de reaproximação com o país do norte até uma nova retomada de posições independentistas.

Importante é o fato de que, sob o governo Dutra, enquanto o Brasil lutava para ser um aliado fiel dos Estado Unidos, este mantinha um certo abandono com relação aos países latino americanos.

Na década de 50 a economia do país passava por dificuldades: o setor de bens de capital e de infra-estrutura básica era suprido por importações. O que também ocorria com os bens de consumo sofisticados. A economia brasileira era limitada. Daí Vargas utilizar a política externa para ajudar o processo de industrialização e modernização da agricultura.

Vargas aprofunda as relações com os EUA, mas ao mesmo tempo procurou a ONU e a União Pan-Americana para não deixar o país isolado em relação à dependência dos Estados Unidos.

A política externa, portanto, foi utilizada para ajudar no desenvolvimento do país. Vargas mais uma vez barganhava ajuda dos EUA, mesmo que de forma ambígua, pois continha um discurso nacionalista. Por exemplo, durante a Guerra da Coréia, Vargas recusou-se a mandar tropas, mas assinou um acordo militar que foi proposto pelos Estados Unidos.

Ainda com Vargas, o Brasil ensaiou uma abertura em direção a países da Europa Oriental e do Oriente Médio como fariam anos mais tarde Quadros e Goulart na PEI. Também foi importante a política desse presidente para unir os países latino americanos.

De Café Filho até metade do governo de JK a diplomacia brasileira voltou a seguir a política norte-americana. O governo de Café Filho foi conservador e voltou às tendências exercidas pelo governo Dutra.

Economicamente, deu grande favorecimento ao capital estrangeiro. As relações exteriores se enquadraram nos moldes da Guerra Fria alinhando-se aos Estados Unidos. As iniciativas de aproximação de paises do leste europeu e da URSS foram abandonadas. O governo passou a ver o multilateralismo com hostilidade.

\footnotetext{
${ }^{1}$ NUNES, Aurimar Jacobino de Barros. Política Externa Independente (1961-1964): Considerações sobre o Homem de Estado. Dissertação (Mestrado) - Universidade de Brasília. Brasília, 1999. p.52.
} 
Durante a primeira metade do governo Kubitschek, o país estava alinhado com os EUA e distante do bloco socialista. A política externa de Café Filho seguiu sempre em direção ao norte.

A mudança que se seguiria estava relacionada com a redefinição do papel internacional do país. A opinião pública nacional e externa exigia que o país assumisse papel mais ativo, principalmente em decorrência dos novos estados independentes africanos e asiáticos.

Na segunda metade de seu governo, Kubitschek retomou a política de barganha frente aos Estados Unidos e um tom nacionalista, encabeçado pela Operação Pan-Americana (OPA). Em 1958, o presidente brasileiro propõe a OPA ao presidente norte-americano Eisenhower, que lha deu pouca receptividade. Mesmo assim os princípios foram aceitos e foi criado o Banco Interamericano de Desenvolvimento (BID).

A atividade diplomática brasileira foi ampliada. Foram abertas embaixadas em vários paises, o Brasil reconheceu muitos dos novos estados africanos e asiáticos e reatou as relações com o bloco soviético.

O nacionalismo e a política externa foram muito estudados e debatidos durante o governo JK. A OPA foi em grande parte uma forma de barganha com os Estados Unidos e isso foi bastante criticado por estudiosos e jornalistas.

$\mathrm{O}$ aspecto econômico ainda era central na política externa durante JK, mas a complexidade dela aumentou bastante sob esse governo. A mudança na política externa era real e sob a Política Externa Independente teve seu maior aprofundamento.

Agora passaremos à análise das estruturas da PEI. Um dos principais aspectos dessa política é a busca por novos mercados. Na segunda metade da década de 50 a União Soviética se aproximou dos paises do terceiro mundo.

Nessa época eclodiu uma onda de nacionalismo e neutralismo no mundo ${ }^{2}$. Era também a época dos não-alinhados. Em outras palavras, a busca por novos mercados como outras políticas da PEI encontraram espaço por causa dessas mudanças mundiais.

\footnotetext{
${ }^{2}$ Idem, ibidem, p.77.
} 
A emergência de novos estados na África e na Ásia alterou o cenário mundial. Também a Revolução Cubana mudou drasticamente a relação dos Estados Unidos com os paises americanos. Surgiram movimentos guerrilheiros nacionalistas nesses paises.

A economia dos paises latino-americanos era agravante: o preço de produtos primários, principal exportação desses estados, diminuiu bastante, dificultando muito o plano desenvolvimentista. Para o Brasil a entrada de nações africanas concorrentes era um incentivo à busca de novos mercados.

A partir de Kubitschek houve no Brasil uma forte política de desenvolvimento. Entretanto, a queda nos preços de café comprometia o processo de industrialização, o que dificultava essa política.

Quanto à economia é possível separar a Política Externa Independente em quatro partes: as políticas econômicas adotadas por Quadros; as políticas dos gabinetes parlamentaristas; implementação e fracasso do Plano Trienal; e a instabilidade econômica do governo Goulart ${ }^{3}$.

Quando Quadros assumiu a presidência, herdou de Kubitschek uma grande dívida externa, inflação crescente, indisciplina fiscal e déficit na balança de pagamento. Em consequêencia, Quadros adotou uma política econômica bastante conservadora e nos últimos meses de 1961 o país caiu em novo período de descontrole econômico.

Na época parlamentarista houve um quadro geral de indefinição e de caráter irrealista. Nessa época as relações do país com os Estados Unidos, com relação à economia, entravam em dificuldades. Somava-se a isso a desvalorização do cruzeiro e o descontrole inflacionário.

Em 1962, tentaram implementar o Plano Trienal. Entretanto, ele relacionouse com o início do processo recessivo da economia brasileira e não deu certo. Neste ano, foi forte o descontrole das contas públicas e o aumento ainda mais da inflação. E por fim, no final do governo Goulart a economia estava em péssimas condições.

É possível relacionar as políticas econômicas durante a PEI com a agitação política interna e esta afetou sobremaneira a formulação e a implementação dessa política externa. No plano doméstico há tempos havia a luta entre "nacionalistas" e

\footnotetext{
${ }^{3}$ Idem, Ibidem, p.85.
} 
“entreguistas”. Eles iriam debater entre si quais seriam as direções da nova política externa brasileira.

Essa briga remonta ao governo Vargas e dividiu o palco político entre “getulistas” e “anti-getulistas”. Dentro dessa divisão se desenvolvia a Política Externa Independente.

Sobre a PEI como meta política, podemos dizer que com ela os governos de Quadros e de Goulart intencionaram tomar parte nos assuntos internacionais importantes e exercer liderança entre os paises subdesenvolvidos. Essa política externa implicou nova relação de poder para o país.

Como dito acima, a situação interna do Brasil era preocupante com múltiplos sinais de deterioração econômica e social. Para Quadros, portanto, a PEI era uma espécie de ação inovadora em oposição à política conservadora interna que foi obrigado a assumir.

A relação entre política interna e externa também pode ser observada na procura por novos mercados para os produtos brasileiros, uma das principais metas da PEI. Esta também possuía forte intenção política. Foi utilizada como meio de se obter maior espaço de manobra e reduzir a pressão de paises como Estados Unidos e Grã Bretanha.

A PEI foi, acima de tudo, um instrumento de desenvolvimento nacional. Ela pode ser dividida em três fases: a presidência de Jânio Quadros apoiando se na idéia de um neutralismo temperado; do ano de 1961 a 1962 com crise interna e necessidade de melhorar o relacionamento do país com os Estados Unidos; e o restante do governo Goulart direcionando a política externa para o desenvolvimento do país ${ }^{4}$. A PEI foi direcionada para várias regiões do globo e é delas que iremos tratar agora.

Com relação à América do Norte, o governo de Jânio Quadros discordava do governo dos Estados Unidos, cujo presidente na época era Kennedy, em relação à maneira como o país norte americano tratava várias questões como a forma de se lidar com a Cuba comunista e a direção do governo brasileiro rumo a uma posição neutra com respeito a várias questões mundiais. Tudo isso representava uma ameaça às relações dos dois paises.

\footnotetext{
${ }^{4}$ Idem, Ibidem, p.101.
} 
O primeiro passo dessa discordância entre os dois estados se deu em um mal falado encontro entre Jânio Quadros e o então embaixador dos EUA no Brasil, Adolf Berle Jr. Jornais da época noticiaram que o presidente brasileiro havia sido rude e que essa reunião teria sido uma afronta aos norte americanos. Na realidade, esses jornalistas exageraram muito suas notícias, não havendo falta de cordialidade, mas sim opiniões opostas dos dois lados.

Como resultado dessas reportagens, os cidadãos e o governo norte americanos ficaram mais atentos e desconfiados da política exterior de Quadros. As opiniões de norte americanos e brasileiros eram diferentes, mas ambos estavam confusos. Mais tarde, em uma declaração, Jânio Quadros negou que era neutralista, enfatizou que o Brasil fazia parte do Ocidente e que possuía valores democráticos, que na verdade, o que o país queria era uma posição independente no mundo e ser amigável com quem quisesse, incluindo os paises comunistas.

O governo brasileiro queria manter relações com o bloco soviético que, de acordo com seu discurso, não poderia ignorar e debater nas Nações Unidas questões como a admissão da China comunista. Ao mesmo tempo desejava manter férteis as relações bilaterais com o irmão do Norte. Com este, Quadros foi ambíguo. Por um lado, como o Brasil possuía uma grande dívida externa e precisava de investimentos feitos do exterior, Quadros tentava satisfazer os EUA, inclusive com as reformas que este exigia para a liberação de empréstimos. Por outro lado, suas ações na Política Externa Independente, mesmo que oficialmente não fossem realizadas contra o país norte americano, desagradavam muito a este.

O governo brasileiro baseava sua política externa em duas bases. A primeira era escapar da pressão exercida pelos Estados Unidos e outros paises ocidentais sobre suas relações exteriores. A segunda era se aproximar de nações que historicamente não eram considerados próximos do país. Isso também tinha um motivo econômico, pois o país precisava encontrar novos mercados, sendo que os dos paises ocidentais eram considerados insuficientes para gerar os investimentos necessários para o Brasil.

O desejo de Quadros por uma maior independência na política externa pode ser comparado ao mesmo desejo com relação à atividade interna. É necessário, primeiro, descrever a situação interna do país. 
Desde 1945 três partidos maiores dominavam o cenário político: o Partido Social Democrático (PSD), o Partido Trabalhista Brasileiro (PTB), que eram aliados, em oposição à União Democrática Nacional (UDN). Para as eleições de 1960, o PTB e o PSD passavam por dificuldades para escolher um candidato que agradasse às massas e realizasse as reformas necessárias. Um partido de menor alcance nacional, o Partido Trabalhista Nacional (PTN) pôs Jânio Quadros como seu candidato presidencial e foi seguido pela UDN e pelo Partido Democrático Cristão (PDC).

Logo após, Quadros recusou a aliança com a UDN, aparentemente por uma discursão entre esta e o PDC por causa da nomeação para vice-presidente, mas já mostrando a tendência de Quadros por ações independentes. Essa foi uma jogada do candidato para conseguir maior independência, pois os partidos, conscientes de suas necessidade por Quadros, o tranqüilizaram de que não seria obrigado a fazer aquilo que seus apoiadores queriam. Após isso, ele reaproximou-se da UDN.

Enquanto isso, o PSD nomeou o marechal Henrique Teixeira Lott como candidato a presidência, obtendo apoio do PTB e de alguns partidos menores restantes. João Goulart foi nomeado candidato à vice-presidência.

As eleições foram ganhas por Jânio Quadros para presidente e João Goulart para vice, pois na época se votava também para a vice-presidência. Logo que foi eleito, Quadros fez várias viagens para o exterior e, em seu discurso, desaprovava a política pró-norte americana de Juscelino Kubitschek. Nessas viagens, recusou convites para visitar os Estados Unidos e a França, mas visitou outros paises como o Egito, Nigéria, Tunísia e Índia.

Em 31 de janeiro de 1961, discursou no rádio para os brasileiros dizendo que o país precisava fazer comércio com todas as nações e que necessitava de uma política soberana. Mais tarde, disse que não apoiaria a dominação econômica e política de nenhum país sobre colônias.

O Brasil passava por uma situação financeira ruim durante seu governo, a inflação era alta. Somado a isso estava um déficit orçamentário e uma grande dívida externa. O governo aceitou fazer reformas para diminuir o déficit público para que o Fundo Monetário Internacional emprestasse dinheiro.

Sobre a Europa a PEI atuou não apenas na parte Ocidental como também na Oriental. Em um episódio em 1961, um navio cruzeiro português foi seqüestrado por 
portugueses contrários ao regime de Salazar. Ao contrário do que o governo português quis, ou seja, ter em mãos os rebeldes, o governo de Jânio Quadros deu asilo aos seqüestradores. O caso acabou sem maiores danos, os passageiros voltaram a salvos e o navio voltou para os seus donos. Mas esse episódio mostrou que Quadros tendenciou a se afastar do tradicional aliado Portugal e mostrou que o governo brasileiro tinha uma tendência anti-Salazar.

O Brasil também adotou uma postura anti-colonialista que será vista nos próximos capítulos.Assim que foi eleito, Quadros começou a negociar seu débitos e a aquisição de novos créditos com a Alemanha Ocidental. Quanto à parte oriental, o presidente desejava uma solução pacífica e queria manter relações com as duas Alemanhas. A parte ocidental, por sua vez, não ficou satisfeita com a manifestação do governo brasileiro e ameaçou cessar a compra do café.

Como esse mercado era importante para o Brasil, Quadros não avançou em seu desejo de manter relações diplomáticas com a Alemanha oriental. A idéia de o Brasil se relacionar com o bloco comunista data a partir dos anos 50, bem antes da PEI, com diplomatas argumentando que o país deveria participar mais das questões mundiais.

Desde essa época, esse assunto era muito discutido por intelectuais, parlamentares e grupos da sociedade. Havia um grande desejo de manter, no mínimo, relações comerciais com a União Soviética. Também havia um consenso de que o país não acompanhava as tendências mundiais, pois era um dos poucos "grandes" paises a não manter relações diplomáticas com a URSS.

Na verdade, o Brasil queria ter mais participação no cenário mundial e ter relações com a outra superpotência, o que considerava essencial. Ao adotar essa política de aproximação com estados comunistas, Jânio Quadros se afastou da tradicional tendência de se submeter às diretrizes das políticas dos principais paises ocidentais.

O quadro geral do governo de Quadros era o seguinte: a política doméstica era aprovada pela opinião pública, mas não pelos comunistas e a política externa era aprovada por estes, porém não pelos Estados Unidos e muitos no Brasil. Era um quadro extremamente contraditório. 
O governo brasileiro realizou várias viagens para os paises do bloco soviético e uma específica para a União Soviética com o objetivo de aumentar suas relações. Os enviados brasileiros discursavam que as diferenças entre os dois estados não impediriam a boa relação entre o dois.

Sobre o continente africano falaremos nos dois capítulos seguintes, aqui traçaremos apenas as linhas gerais da aplicação da PEI nesse continente. No final dos anos 1950, a emergência das novas nações africanas coincidiu com a procura por novos mercados pelo governo brasileiro. O Brasil se aproximou da região do norte da África arábica, da África sub-saariana e da África do Sul. Várias idéias como a identificação do Brasil com a África pelo seu passado e a miscigenação brasileira faziam uma aproximação ideológica com os paises desse continente.

A República Unida da Arábia e a Yuguslávia chamaram os representantes da América Latina para uma reunião com os paises neutros. O Brasil não participou diretamente, mas apenas como observador. Em outras palavras, o país teve uma política passiva e como observador para a região arábica da África.

Quanto à área sub-saariana, o governo brasileiro estava interessado pelos afro-brasileiros internamente, e em melhorar as relações com os paises africanos externamente. Por ter uma população grande de negros e por seu passado que o ligava ao continente africano, o Brasil sentia certa solidariedade com esse continente.

De 1850 a 1950 não houve nenhuma pesquisa significante de brasileiros sobre a África. Com essa aparente falta de interesse pelo continente africano e a influência da América do Norte e da Europa sobre o país, as relações entre os dois ficaram esquecidas. Isso muda a partir de Jânio Quadros.

Em 1954, Adolpho Justo Bezerra de Menezes escreveu um livro chamado $O$ Brasil e o mundo Asio-Africano que influenciou a diplomacia brasileira. Com a ascensão de novas nações africanas, esse continente ganhava mais importância no contexto mundial, principalmente nas Nações Unidas. Muitos brasileiros achavam que o país era indicado para liderar paises asiáticos e africanos e essa idéia agradava Quadros.

No começo de seu governo, existia um grupo contrário à diplomacia autônoma, que consistia em pessoas que possuíam interesse econômico nos Estados Unidos. Eles interpretavam qualquer passo que a diplomacia tomava rumo à 
autonomia como um movimento a favor do comunismo. Achavam que era um erro se aproximar dos paises africanos e asiáticos.

Outros grupos pensavam que o Brasil não deveria se meter na luta entre os EUA e a URSS sobre os novos estados africanos. Jânio Quadros discursava sobre essa aproximação desde os tempos de sua campanha para presidência. Quando eleito, essa política para o continente africano não foi surpresa. Muitos viram nela uma forma de escapar da velha definição do Brasil como um país latino americano satélite dos Estados Unidos ou da Europa.

Quadros foi o primeiro presidente brasileiro que conheceu muitos dos paises do mundo e não apenas os EUA e o continente europeu. Em relação à África, expôs o passado brasileiro como um lugar comum com o continente.

Visava também a formação de novos mercados para os produtos brasileiros. O governo brasileiro enxergava o seu país como uma futura ponte entre os dois continentes, como um líder para nações não industrializadas.

A PEI também teve aplicação no Oriente. A China já possuía sua política para a América Latina desde os finais dos anos 50. Ela queria melhorar as relações com esses paises e incrementar o comércio. Os governos de Quadros e de Goulart foram a favor dessas investidas chinesas e fomentaram políticas comerciais agressoras com a aquela nação. A partir da experiência com a China, o Brasil passa a incentivar relações diplomáticas com outros paises orientais.

As relações brasileiras com o Oriente sempre foram irregulares. Como dito acima, a China, ao se tornar comunista, implementou uma forte política nos estados latino americanos, abrindo embaixadas em vários paises da região.

A China comunista possuía, porém, atividades relacionadas com os partidos comunistas regionais. Os governos de Quadros e de Goulart, entretanto, só objetivavam as relações comerciais. Quadros visualizava os milhões de chineses como um possível mercado para os produtos brasileiros.

O Brasil realizava sua política externa no Oriente sob dois objetivos: procurar novos mercados fora dos tradicionais aliados e manter relações sem discriminar nenhuma nação.

Visando esse objetivos, Quadros reconheceu a China comunista e rompeu relações com Taiwan, embora houvesse muitos que gostariam de uma política 
contrária. Ainda foi a favor de incluir a China comunista nas Nações Unidas. As relações dos dois estados sofreu um agravamento com a prisão de supostos espiões chineses em 1964. Com o golpe militar no mesmo ano, a política chinesa para o Brasil teve seu fim.

Quando Quadros assumiu a presidência do Brasil, ele possuía certas idéias em relação à América Latina. Nutria sentimentos simpatizantes pelo regime de Fidel Castro em Cuba.

Fidel representava para o presidente brasileiro um símbolo de independência em relações internacionais. Porém, quando Cuba se mostrou dependente da União Soviética, a esperança do Brasil em construir uma América Latina neutra em relação à Guerra Fria diminuiu.

Mesmo assim, o Brasil foi contra a tomada de ações contra a Cuba comunista, em grande parte por que queria expandir as relações com esse país e por que uma intervenção contra ela podia trazer problemas para a PEI. Também procurava apoio das nações americanas para combater o subdesenvolvimento como a melhor forma de evitar o comunismo.

Quanto ao resto da América Latina, Quadros adotou uma política visando a unidade do continente, uma liderança brasileira e maior independência face aos EUA.

Em 25 de agosto de 1961, Jânio Quadros renunciou. Ele era pressionado por diversos grupos nacionais e alguns internacionais. Mesmo assim sua renúncia foi um ato estranho e deixa muito mistério sobre suas causas.

Pela Constituição de 1946 e que estava vigente na época, o Vice assumia a presidência após a renúncia do presidente. Os militares eram contra a presidência de Goulart, pois o consideravam liberal em excesso. Do outro lado estavam outros militares, políticos e figuras públicas que queriam garantir a legalidade da Constituição. Goulart teve a presidência, porém com poderes reduzidos pelo parlamentarismo.

Seu governo pode ser dividido em duas partes: quando governou sob o parlamentarismo e quando possuiu poderes completos. Na primeira fase, lutou para obter poderes completos; na segunda, contra problemas internos. 
Teve que concentrar muita energia nesses problemas domésticos, deixando pouco tempo para a política externa. Seguindo seu predecessor, fez esforço para manter a PEI, mantendo relações com todos os paises fossem eles comunistas ou capitalistas.

O governo de Goulart reafirmou a não intervenção e a auto-determinação em relação à Cuba. No encontro da Organização dos Estados Americanos em Punta del Este, o país defendeu a auto-determinação dos povos e a volta de Cuba para a organização. Goulart enfatizou seus princípios anti-comunista e democráticos. Restabeleceu relações diplomáticas com a União Soviética e outros países da Europa oriental e manteve a política de procurar novos mercados para o Brasil. 


\section{CAPÍTULO II - DESCOLONIZAÇÃO AFRICANA}

A Política Externa Independente aplicada à África, tema do próximo capítulo, está diretamente relacionada com a descolonização africana. Por isso, é sobre esta que iremos falar no segundo capítulo.

No pós-Segunda Guerra Mundial, com o advento da Guerra Fria, o mundo estava dividido entre as duas grandes potências, os EUA e a URSS. O sistema colonial pelos estados europeus já não possuíam respaldo ideológico, tornando-se obsoleto.

A Segunda Guerra dissipou os recursos financeiros e políticos dos paises europeus deixando um espaço vazio no antigo sistema internacional em relação ao sistema colonial. Após a guerra, o mundo passou de um sistema multipolar cujo centro era a Europa para o sistema bipolar entre os Estados Unidos e a União Soviética.

Nenhuma das superpotências via com bons olhos o sistema colonial, porém o processo de descolonização foi um problema tanto para uma como para a outra. Os dois tentaram, a princípio, enfrentar a questão dentro dos moldes de suas esferas de influência.

Para os EUA, se tratava de uma questão de segurança. Durante o governo Roosevelt (1933 - 1945), tinha se a idéia de exportar para o mundo o ideário de democracia e liberdade, porém, na administração de Truman (1945 - 1953) ocorreu uma mudança de enfoque, uma idéia de que as colônias pertenciam à Europa que era sua aliada.

As colônias eram vistas como recurso para ajudar a Europa ocidental a frear a expansão soviética. Esta visão durou até final dos anos 40 quando a Europa se estabilizou. Mesmo assim, o colonialismo foi considerado como um aspecto dentro do modelo de segurança.

Os Estados Unidos exerceram uma política de status quo, ou seja, objetivavam manter as colônias para não desestabilizar o sistema internacional. Também se preocupavam pois não saberiam de que lado da Guerra Fria os novos 
paises ficariam. O posicionamento norte-americano era o de que se os paises não se aproximassem dele é por que seriam pró-soviéticos.

Já a URSS via se em competição com os EUA. Com relação a descolonização, pode se dividir em duas fases: a primeira até meados dos anos cinqüenta, favorável à descolonização; a segunda, sob a administração de Khrushchev, de aproximação com os novos estados ${ }^{5}$.

A União Soviética era mais favorável a descolonização que os Estados Unidos, pois, ao contrário destes, não possuía aliados que tinham colônias. Por outro lado, a URSS não dispunha dos meios necessários para abarcar os novos paises, sua força produtiva não a permitia.

As metrópoles já não possuíam a mesma força que antes, as condições eram adversas sofrendo várias pressões, principalmente da União Soviética. Tentaram em um primeiro momento reestruturar o sistema colonial, modernizando-o. O que ocorria é que esses estados perderam espaço para a Guerra Fria e precisavam fortificar os modos produtivos internos.

O pólo de poder mundial passara da Europa para Washington/Moscou e as decisões das potências coloniais ficaram em nível secundário. Daí que a descolonização ganhou um novo aspecto. Além disso, em decorrência da Segunda Guerra Mundial as metrópoles se tornaram mais fracas e mais dependentes de suas colônias.

Em razão dessa fragilidade as metrópoles aumentaram a pressão, exigindo mais dos colonos para a reconstrução e fortificação de suas economias. Alguns estados coloniais, percebendo a impossibilidade de manter o controle, estavam dispostos a barganhar e tentavam manter seu domínio sobre outras áreas que não a política.

Portanto, as metrópoles possuíam problemas internos, a fragilização de suas estruturas pela Segunda Guerra, e globais, passando a serem espectadores em vez de protagonistas do sistema mundial.

As relações entre metrópole e colônias na descolonização ou foram violentas ou foram pacíficas. Grande parte da violência se deve ao autoritarismo das

\footnotetext{
${ }^{5}$ SOUZA, Creomar Lima Carvalho de. Do conservadorismo ao Desinteresse - Três estudos de caso sobre o posicionamento brasileiro frente à descolonização Afro-asiática (1946-1961). Dissertação (Mestrado) - Universidade de Brasília. Brasília, 2005. p.12.
} 
autoridades dos paises europeus ao tratar com as lideranças nativas africanas que estavam ligadas a movimentos nacionalistas. E os processos pacíficos foram resultados de um ambiente propício à negociação. Não que não houvesse conflitos, mas esses foram em menor escala.

Em grande parte das negociações não havia consenso entre as partes e muitas vezes existia a questão de descendentes de europeus que não viam caminho fora das colônias. Esses foram casos violentos. Nos pacíficos, as autoridades européias cumpriram suas promessas de ajuda e maior autonomia.

Em geral, as negociações foram tomando rumos diferentes dos que queriam as autoridades européias e elas acabaram por perder o controle, ressaltando o nascimento de vários estados.

O número de paises novos aumentou entre 1945 e 1960. O palco de atuação deles por excelência foi a ONU. À medida que esse número foi aumentando, crescia a importância de se debater o assunto da descolonização.

Para os estados novos, a busca por independência confundia se com a busca por uma identidade nacional que os unissem domesticamente e os distinguissem internacionalmente. Muitas das colônias tentaram se afastar das antigas estruturas internas impostas pelas metrópoles, rejeitando o que considerava atraso. Outros criaram mecanismos ideológicos que unissem a população e lha desse uma atitude com mais auto-estima.

Nesse contexto, ganhavam muita importância as políticas desenvolvimentistas e modernizadoras. Esses projetos se encaixavam na idéia de inserir os novos estados no conjunto internacional. Foram vários os programas de crescimento da economia, fomentando a agricultura e o setor exportador. Infelizmente para eles muitas delas alcançaram o efeito contrário, aumentando a dependência do capital externo e retraindo suas economias.

Muitos desses novos estados aproveitaram os interesses comuns - mesmos que muito poucos - para tentarem um movimento de maior alcance. Esse foi o movimento dos paises não-alinhados ou terceiro-mundo, que alcançou certo respaldo na ONU.

No Brasil, a vontade de se aproximar do estado norte - americano impediu que o país entrasse mais afundo na questão da descolonização. No tocante à África 
subsaariana, o fim das colônias teve inicio com a independência de Gana, em 1957 e representava o começo do desaparecimento da dominação ideológica e concreta do europeu sobre o africano.

Na Segunda Guerra Mundial, os africanos perceberam que o colonizador não era invencível e mostrou que em certa medida várias metrópoles eram dependentes de suas colônias. Os estados europeus que participaram diretamente da guerra se viam na dependência de utilizar os recursos provenientes de seus territórios coloniais. Já os que não participaram do conflito, como Portugal e Espanha, mantiveram o status de dominador soberano sobre suas colônias. O que mais tarde desenvolveu se em luta armada pela independência africana.

Fora isso, deve se ter em mente que nenhuma nação se viu a parte do sistema bipolar que se impôs e na qual a importância da Europa passou a ser secundária. Esse novo molde internacional ajudou no amadurecimento dos paises africanos lhes deu a percepção de que sofriam injustiças e de que seus interesses eram diferentes dos do colonizador.

Durante a guerra, diante da necessidade de vencer o inimigo os europeus fizeram várias promessas a seus colonos, promessas essas que não foram compridas, pois depois da guerra surgiu o problema de reconstrução de seus estados utilizando os recursos das colônias. O que contribuiu grandemente para o desejo de independência dos africanos.

Tudo isso fomentou os movimentos nacionalistas africanos. Porém, não é possível falar em um nacionalismo na África, pois as diferenças entre os paises são grandes. Entretanto, há pontos em comum nesses discursos nacionalistas.

Entre os colonizados, existia uma elite educada à maneira ocidental, na qual se deu o começo do nacionalismo nesses paises. Essas elites utilizaram armas políticas européias para lutar durante a descolonização.

Somava se a esse discurso as características étnicas dos diversos grupos aumentando as diferenças na medida aumentando as diferenças na medida em que especificava os movimentos. Os componentes étnicos enriqueciam o nacionalismo, que nascia timidamente, aproximando o grupo e o individuo aos movimentos de libertação. 
As elites africanas perceberam que a hostilidade aos europeus juntava se à defesa de interesses próprios, daí tomaram pra si a luta pela liberdade da colônia. Esta foi, em geral, a dinâmica dos processos de libertação na África subsaariana.

Para tanto, elas necessitavam criar uma identidade comum, tentando apagar as diferenças enfatizando as semelhanças. Na África, como em todos os lugares do mundo, existiam rivalidades que foram criadas entre os africanos, por eles mesmos, durante a fase colonial. Elas atrapalhavam a construção da identidade comum, por isso tentou se deixa-las de lado - somente na aparência, é claro - criando um inimigo comum, a metrópole. Esta, por sua vez, criava, no discurso nacionalista, as semelhanças entre os grupos, ao classificar todos como dominados.

Em outras palavras, as elites nativas, burguesias locais, buscavam na situação política existente a construção da identidade nacional. Essa fórmula, em grande parte trouxe problemas no futuro pós-independência, mas esse é um assunto que foge ao seguinte trabalho.

A descolonização teve um fator complicador, os descendentes de europeus, como dito acima. Eles se vinculavam, em geral, no setor agrônomo e como o principal setor desses novos paises era o do produtor primários, a situação ficava complexa. Em muitos paises, essa burguesia branca dominou a economia. Essa situação provocou violentos conflitos sociais durante a descolonização.

Porém, também houve transições pacíficas, que não conduziram à violência por que a metrópole pôde manter razoavelmente seus interesses economias nas regiões. Nelas ocorreu uma negociação entre os europeus e uma elite nativa que projetou se na política nacional.

Já quando houve violência, e nos vários casos houve uma divisão de forças entre os que queriam mudanças e os que desejavam manter a situação. Muitas vezes isso acabavam em conflitos contra a metrópole seguindo se em guerras civis. Diferentemente de outros lugares onde a elite nativa foi paulatinamente exercendo maiores funções até alcançar o poder pleno.

Nas colônias onde haviam brancos fazendeiros ricos, a transição foi conflituosa. Os interesses africanos contrários aos dos brancos obrigavam a metrópole a fortificar a segurança dentro das colônias. Esses fazendeiros brancos se 
recusavam a ceder espaço aos africanos, deixando como soluções para estes a submissão e a subexistência ou a alternativa à violência.

De fato, o mundo pós-segunda guerra era tão complexo que os interesses dos grupos nativos se inseriam em uma teia de diversificação de desejos e anseios e batiam de frente com várias políticas européias, norte americanas e soviéticas. A descolonização recebia papel de destaque nas relações internacionais, mas não era o único assunto importante. Concorriam com ela questões como a energia atômica e a guerra nuclear.

Se voltarmos alguns anos antes da Segunda Guerra Mundial veremos que o processo de colonização não foi de forma alguma pacífica. Os povos africanos já lutavam contra os europeus dominadores antes da guerra. Portanto, o desejo de independência não é novo. Inúmeras guerras foram travadas no interior da África para tentar acabar com a dominação. A luta contra a dominação jamais deixou de existir nesse continente.

Como dito acima, existiam rivalidades históricas entre tribos africanas. Uma das armas dos colonizadores foi incentivar essas rixas étnicas. Com o fim da guerra as nações européias chamaram - ou usaram - os povos africanos para a reconstrução dos seus estados destruídos, o que de certa forma uniu um pouco as etnias africanas em torno de um objetivo.

Durante a guerra, os europeus precisavam de toda ajuda que conseguissem. Foi dispensado ao negro tratamento igual ao branco, principalmente em razão da necessidade de recursos do continente africano e a própria luta armada contra os alemães por parte de alguns grupos negros em seu próprio território. Isso fez com que a mentalidade dos grupos nativos mudasse e visem com indignação cada vez maior a submissão que lhes era imposta.

Para as elites nativas a independência era o maior desejo e ofuscava questões importantes como a viabilidade econômica de um novo pequeno estado na África. Isso contribui para explicar a falta de estratégia e a má organização dos novos paises africanos.

Tanto a situação externa quanto a interna contribuíram para o processo de descolonização. Não só as elites nativas desejam a independência e se organizavam para alcança-la como também sindicatos, igrejas, artistas, escritores e estudantes. 
Nesses grupos se debatia a questão da independência e era maior o desejo de liberdade, esta como sinônimo de fim do colonialismo. Se o país cairia em dependência econômica e política depois da descolonização era um assunto debatido, mas secundário em razão do forte desejo de se libertar de uma vez por todas do julgo colonial.

Surgiram movimentos como a Negritude e o Pan-Africanismo que se propunham a criar uma consciência negra resgatando as culturas africanas, defendiam a união e a emancipação da África. Em geral, foram bandeiras de lutas e símbolo para os que lutavam contra o colonialismo.

À medida que o assunto da descolonização ganhava maior importância no mundo, principalmente na ONU, o conceito de autodeterminação dos povos assumia maiores proporções. De fato foi uma das principais armas ideológicas e jurídicas dos povos africanos contra a colonização, alcançando respaldo político em várias partes do mundo.

Após muita luta, com uma conjuntura mundial favorável e com apoio internacional, vários paises africanos conseguiram sua independência nos anos 50, mas não deixaram de ser dependentes em várias formas nem significou o fim de seus problemas. É bom lembrar que várias áreas do continente continuavam sob domínio europeu.

No processo de descolonização em geral ou as elites nativas entravam em negociação com as metrópoles ou conseguiram sua independência por meio de intenso movimento de libertação chegando em alguns casos à guerra contra os europeus.

Nas negociações os estados europeus agiram pacificamente e conseguiram manter laços fortes com as ex-colônias, principalmente econômicos. Muitos paises africanos independentes continuaram tendo forte relação com a Europa, muito pelo desejo desta.

Já os paises europeus que agiram intransigentemente com os africanos se viram em uma situação desagradável. Distanciaram-se das ex-colônias. As guerras de libertação nacional foram custosas tanto para um como para o outro lado.

Como já analisado, a descolonização se imbricava à Guerra Fria. Uma “escolha” que os paises novos tiveram que fazer era de que lado ficariam. $\mathrm{Na}$ 
verdade, os processos de independência e os movimentos de libertação é que os conduziram a um ou outro lado, isto combinado pela pressão exercida simultaneamente pelos EUA e pela URSS.

A democracia na África, analisada historicamente, era precária e instável. Os paises sofriam contínuos golpes de estado e surgiam diversos regimes ditatoriais. Isso se deve muito à má situação interna e vários conflitos sociais.

Motivos semelhantes também levaram ao insucesso dos paises que adotaram o regime comunista. Somava-se as lutas internas motivadas por interesses externos. Neles havia vários conflitos armados, muitos deles começavam como regionais, mas acabavam alcançando maiores proporções a medida que se tornavam mais ligados à ideologia.

Em geral, os paises africanos, após sua independência, se caracterizavam por uma grande instabilidade. Ela se agrava quando se analisa o sistema econômico herdado do colonialismo, que colocou esses paises na periferia do capitalismo. As rivalidades entre os africanos não desapareceram, aumentaram com a corrupção e a exploração e exclusão das camadas populares pela burguesia nativa.

A dependência econômica era tão grande que faltavam aos africanos um mercado interno, logo a economia era gerada de fora para dentro, sendo que algumas nações possuíam um único produto forte para exportação.

E como o Brasil vinha reagindo à colonização e a descolonização? Em primeiro lugar, devemos saber que a crescente consideração do país com a África está relacionada com as mudanças que esse estado vinha passando. O que a Política Externa Independente aprofundou já vinha sendo pensado em vários momentos desde o final do Estado Novo, pelo menos no que concerne às percepções sobre aquele continente.

O Brasil dos anos 50 foi um estado conturbado, com uma democracia não muito forte. Os grupos nacionalistas formavam o Partido Social Democrático (PSD) e o Partido Trabalhista Brasileiro (PTB), poderosos na política nacional. Esses grupos visavam um desenvolvimento do país em caráter nacionalista. Assim influenciaram a forma como a nação enxergava a África.

A industrialização do país foi prioridade para o governo brasileiro que queria o desenvolvimento econômico a todo o custo e a política externa, não poucas vezes, 
foi utilizada para alcançar recursos necessários ao desenvolvimento. Assim, o Brasil se aproximou dos Estados Unidos, que era a maior fonte de recursos financeiros, confirmando sua inserção no bloco ocidental e capitalista.

Porém, com o acirramento da Guerra Fria, os interesses dos EUA estavam distantes da América Latina que, até a Revolução Cubana, era considerada livre do comunismo. Logo a busca pela aproximação com esse país perdeu espaço, mas de maneira excessivamente lenta.

De acordo com Creomar Lima Carvalho de Souza essas visões internas e externas influenciaram o Brasil a agir de forma conservadora, principalmente em razão de como o governo agiu em relação à Guerra Fria. ${ }^{6}$

Falaremos brevemente sobre a relação do Brasil com Portugal. Para este, a descolonização foi muito negativa, tal era sua dependência das colônias africanas. Como todo o processo de independência de suas colônias ultrapassa o período da PEI não trataremos dele todo, apenas no que diz respeito aos anos 50 e começo dos anos 60.

Como dissemos, Portugal precisava defender o statos de metrópole. Para isso, se aproximou do Brasil buscando argumentos no discurso de Gilberto Freyre. Portugal queria o Brasil, como uma "ex-colônia que deu certo", para a defesa de suas possessões na África.

No Brasil, havia muitos grupos, além de portugueses residentes no país, que eram favoráveis a Portugal. Este fez diversos eventos para captar o apoio dos intelectuais brasileiros, conseguindo-o. Grande maioria dos meios de comunicação importantes do Brasil demonstrou seu apoio aos portugueses.

Contribuía para isso, durante o governo de Café Filho, a falta de um projeto de política externa e a percepção de que, para se chegar à África, era preciso passar pela Europa. De fato, o Brasil ajudou Portugal prejudicando as colônias deste país no continente africano.

A percepção sobre a África foi construída ao longo do tempo. A ação da PEI nesse continente era diferente da dos governos anteriores ao governo de Quadros. A visão desenvolvimentista não encaixava os paises africanos dentro de seus objetivos e metas.

\footnotetext{
${ }^{6}$ SOUZA, Creomar Lima Carvalho de, op.cit., p.50.
} 
O Brasil desejava industrializar se, mas ainda dependia muito de seus produtos primários. A África, nesse contexto, foi percebida como concorrente dos produtos brasileiros. Desconfiava se dela e a tratava como rival, pelo menos no campo econômico.

Depois da Segunda Guerra Mundial a África entrou, mesmo que minimamente, na agenda das relações internacionais do Brasil. Desde que houvesse a concordância das antigas metrópoles e legalmente, o país reconhecia novas nações africanas.

A visão de uma África rival se fez mais no governo kubitschek, quando o viés econômico da política externa foi prioridade. Esse continente possuía economia semelhante à brasileira, exportadora de produtos primários. O sistema colonial havia legado essa herança a eles e também havia a questão do clima que era apropriado para produtos como o café, o algodão e o cacau, produtos exportador pelo Brasil.

Embora essa percepção tenha sido forte no governo JK, ela não começou ai. Havia vários estudiosos que alertavam para essa característica da economia africana. Existia ainda o fato de que eram essas colônias que forneciam os produtos para os paises europeus e o Brasil desejava mais mercados para vender seus produtos.

Sob a administração de Kubitschek, o preço dos produtos primários caiu e as exportações diminuíram, como o Brasil precisava de capital para industrializar-se o debate sobre a rivalidade africana ganhou grande alcance.

Além disso, os pontos de vista de produtores brasileiros não convergiam com os dos euro-africanos, principalmente com relação a produção do café. Foram feitas reuniões para tentar determinar o preço do produto, mas não chegaram a um consenso. ${ }^{7}$

Em geral, sempre que algum país africano conseguia ajuda para sua economia, ou seja, para vender seus produtos primários, o Brasil reclamava. Temiase a perda de mercados, principalmente europeus, para os produtos africanos e a concessão de privilégios da Europa para as nações africanas.

O Brasil, por várias vezes, denunciou a exploração do trabalhador africano nesses paises, o que poderia render competitividade a eles, ou seja, que seriam

\footnotetext{
${ }^{7}$ PENNA FILHO, Pio. O Brasil e a descolonização da África nos anos Kubitschek (1956-1961): Ensaio de mudança . Dissertação (Mestrado) - Universidade de Brasília. Brasília, 1994. p.112
} 
competidores desleais. Assustava o Brasil a ligação especial que os novos paises teriam com as nações européias.

Entretanto, no mesmo tempo que temia essa rivalidade, o Brasil lutava em organismos internacionais, principalmente na ONU, para o desenvolvimento daquele continente com vistas a acabar com a concorrência desleal e já visando a construção de mercados para o parque industrial que o país batalhava para aumentar.

Os paises africanos, por sua vez, tinham consciência da percepção que o Brasil possuía deles, mas, ao invés de ir contra o país sul americano, tentaram ganhar sua ajuda contra o colonialismo dizendo que, após conseguirem a independência, cooperariam com o país na questão dos produtos primários, principalmente o café.

Durante o governo de Kubitschek, as relações comerciais do Brasil com a África eram praticamente inexpressivas. Na verdade, havia um grande desinteresse do país com o continente africano e será só na segunda metade dos anos 50 que essa situação iria mudar. Primeiramente, foram os africanos que se interessaram pelos brasileiros, principalmente para conseguir apoio contra o colonialismo.

Sobre a relação do Brasil com a descolonização houve uma posição ambígua de sua parte, pendente muito mais para o colonialismo do que para a independência dos africanos. Vista dessa forma, podemos perceber quão grande foi a inovação que a PEI trouxe para o Brasil.

A opinião pública internacional era a favor da descolonização. Algumas nações européias teimavam em continuar sua dominação. A conjuntura mundial pendia para o lado dos africanos. Nesse difícil contexto, o Brasil tentava se inserir e defender seus interesses.

Economicamente, como já dito, o Brasil enxergava a África como concorrente; culturalmente, as semelhanças entre os dois não chegava a influenciar o governo JK e politicamente, este governo não enxergava vantagens na aproximação.

O que ocorria é que o Brasil queria ficar ao lado de aliados históricos como os Estados Unidos e a Europa ocidental e isso dificultava o apoio à África. Tanto é assim que foi preciso a articulação de uma política mais inovadora, nova e progressiva como a PEI para dar uma guinada para novos rumos.

Outra questão influenciadora na questão era o preconceito racial de parte das autoridades brasileiras. Na história do Brasil são vários os casos em que o imigrante 
branco era mais bem visto que os negros ou asiáticos. Era preferível para os donos do poder que, se o país precisasse de imigrantes, que viessem brancos europeus para o território brasileiro.

Embora esse preconceito existisse, o discurso oficial era de uma nação sem discriminação racial. Essa propaganda foi utilizada por Portugal para justificar sua colonização. Logo, o Brasil foi usado por esse país contra a descolonização e como o governo brasileiro queria manter as boas relações com o estado europeu, ele contribuiu para a estratégia portuguesa.

Enfim, embora houvesse quem defendesse a África, o Brasil manteve sua tendência pró-colonialista, em parte pela sua disposição de apoiar os Estados Unidos, Portugal e outros países europeus. Com a PEI isso iria transformar-se. 


\section{CAPÍTULO III - POLÍTICA EXTERNA INDEPENDENTE APLICADA À ÁFRICA}

Esse último capítulo trata da PEI aplicada na África. Antes de entrarmos nessa política externa, convém analisarmos a história das relações entre o Brasil e a África. Portanto, faremos um breve resumo dessa história aqui. Assim, mostraremos quais as influências históricas que ajudaram os tomadores de decisão do governo Quadros e Goulart a fazerem sua política externa para aquele continente.

As relações dos dois começam na pré-história quando os continentes formavam um único bloco de terra. Parte do Brasil, principalmente o nordeste tem clima semelhante ao oeste africano. Os dois possuem clima tropical, vegetação e abundância de minerais.

No século XVI com a colonização de Portugal, tanto no Brasil como em parte da África, houve uma forte imigração forçada de africanos para a América portuguesa, era a escravidão. Milhares de escravos negros foram obrigados a deixar seus lares e migrar para as terras brasileiras. Isso continuou até o século XIX com a abolição da escravatura. Esses africanos contribuíram para a formação do Brasil e qualquer estudo sério sobre a cultura brasileira deve passar pelos escravos e descendentes africanos.

Os africanos introduziram várias culturas dentro do país sul americano. Trouxeram sua religião, sua música e sua gastronomia para ficar apenas nessas três características africanas. Talvez a mudança mais significativa com a chegada deles foi a miscigenação. Mulatos, morenos, negros, todos alteraram as relações sociais existentes na colônia portuguesa e mudaram para sempre a vida no estado brasileiro.

$\mathrm{Na}$ independência brasileira, com o Brasil Imperial as relações oficiais com aquele continente eram poucas. Talvez pela origem européia de Dom Pedro I havia um desinteresse geral pelo continente. Contribuía para isso o racismo brasileiro e o fato das autoridades brasileiras na política externa serem majoritariamente brancos.

A escravidão era algo, talvez a única coisa, que relacionava o Brasil com a África. Nesse século a Inglaterra, principal potência mundial, pressionava o governo brasileiro para acabar com a escravidão, que era o que ligava, negativamente falando é claro, o país àquele continente. 
Foram fomentadas políticas com vistas à imigração européia, de brancos, para “embranquecer” a população nacional que era composta principalmente por mulatos e negros. Assim, negligenciavam e até afastavam a África da vida política dentro do país.

Até 1889, o principal elo de ligação com a África eram os escravos e depois os recém libertos, muitos deles cumprindo o desejo de regressar àquele continente. Nos primeiros anos da República, o Brasil abriu seus primeiros consulados no continente africano. Isso foi no governo de Floriano Peixoto (1891-1894) e no de Prudente José de Morais (1894-1898).

Durante a era de Rio Branco, nos anos em que ele assumiu a liderança da política externa, sua atenção à África foi mínima, com exceção de Cabo Verde e Marrocos. Durante a Primeira Guerra Mundial as relações esfriaram, mas após o seu fim, foram autorizadas várias missões para a África subsaariana. Até 1930 foram abertas mais consulados nesse continente e foram feitas muitas missões. Nos anos 20 o governo brasileiro autorizou várias linhas aéreas européias a estabelecer conexões entre o território brasileiro e o africano.

Sob o primeiro governo de Vargas, foi aberto um consulado no Cairo. O presidente deu atenção às colônias britânicas na África. Foram abertos também consulados no Marrocos, Cabo Verde e foram assinados tratados com as colônias francesas.

De 1930 a 1945 o comércio com o continente aumentou bastante. Ainda era muito pouco, mas já representava um avanço em comparação com os séculos anteriores. Entretanto, as relações eram dificultadas pela Conferência de Berlin que repartiu a África entre as nações européias, deixando todos os outros estados fora. Por esse motivo o Brasil não incrementou suas relações com o continente africano.

Durante a Segunda Guerra Mundial, essas relações foram quase inexistentes. A principal função dos consulados brasileiros naquele continente ainda abertos era informar as ações dos paises do eixo naquela região ${ }^{8}$.

Depois da guerra, o Brasil tentou estabelecer uma liderança no multilateralismo e aumentar sua participação na política mundial. Assim, a África mais uma vez ganhou importância para o país. Sob o governo Dutra o interesse no

\footnotetext{
${ }^{8}$ ARAGÓN, Daniel Patrick. Brazilian Foreign Policy in África, 1961-1976. Tese (Doutorado) Auburn University. Alabama, 2001. p.28-29.
} 
continente foi pouco, apenas com alguns tratados. Porém, no final de seu mandato tomou ações a favor dos africanos.

Já no segundo governo Vargas (1951-1956), o governo brasileiro deu mais atenção aos paises africanos. Em 1951, a delegação brasileira na ONU votou a favor do debate naquela organização sobre a independência da Tunísia. Com exceção das colônias de Portugal, um assunto a parte para o Brasil, o país ficou a favor das colônias africanas, pedindo às metrópoles que melhorassem as condições financeiras e sociais na África.

Com a morte de Vargas e a ascensão de Café Filho à presidência, o país retirou seu apoio aos africanos. Café Filho e seu governo eram pró-colonialismo. Ordenou aos seus delegados que não atacassem as potências coloniais, mas que fossem a favor da melhoria de vida dos africanos. Porém, evitava o apoio à independência das nações africanas. Esta, de acordo com o governo brasileiro, viria naturalmente com o amadurecimento das estruturas e instituições africanas.

Sob o governo Kubitschek, o foco com relação à África foi a descolonização e sobre esse tema já tratamos no capítulo anterior. Falando diretamente sobre a PEI, sua aplicação ao continente africano pode ser interpretada como um movimento dentro de uma política de re-inserção do Brasil no cenário internacional. Nessa política externa ocorreu o nascimento da política africana do Brasil. Como dito no primeiro capítulo, vários momentos da história política brasileira influenciaram os governos de Quadros e Goulart, o mesmo pode ser dito com relação a política africana, mas em menor escala.

Aconteceu uma ruptura com os anos anteriores, principalmente com a política pró-Portugal do governo Kubitschek. Essa ruptura foi conseqüência das mudanças mundiais e do país que ocorriam na década de 50. Juntou se a isso a procura por novos mercados que o país fazia há anos. Portanto, as mudanças se juntaram à continuidade de certas políticas e transformaram a política externa na administração de Quadros e Goulart.

As novas forças que pressionaram o país e a busca por opções de sair dessa pressão levaram as autoridades a uma releitura da política externa. Como vimos na capítulo , o Brasil não cortou os laços históricos com países como Estados Unidos e 
Inglaterra, o que fez foi aumentar seu campo de manobara buscando mais autonomia. A aproximação com a África se encontra dentro desse movimento.

A nova política para a África era anti-colonialista e anti-racista, apoiando o princípio de autodeterminação dos povos, que foi muito defendido pelos africanos na ONU. Para Quadros, o Brasil e a África possuíam interesses semelhantes, sejam eles o desenvolvimento econômico, o preço dos produtos primários ou a industrialização. Note que houve um rompimento com a visão de concorrência com aquele continente que se tinha nos anos anteriores.

Essa percepção significava a nova postura brasileira diante das mudanças mundiais, um mundo menos polarizado onde ganhavam espaço movimentos como o dos paises não alinhados e do terceiro mundo.

Uma ruptura clara era com os paises colonizadores. O Brasil não mais apoiaria a colonização, via agora com entusiasmo a independência de paises africanos e comparava o desenvolvimento do país com o daquele continente.

Era uma questão moral, para os governos Quadros e Goulart, a aproximação e o apoio às nações africanas. Dizia se que o Brasil deveria agir assim, pois possuía uma dívida imensa com o povo africano. Demonstra se assim a nítida oposição à visão pró-Portugal dos governos anteriores.

Como dito acima, o Brasil não queria romper as relações com o bloco ocidental. Assim, propôs que a influência brasileira na região da África iria contrapor se à presença soviética. Era também para o país uma questão de segurança.

No Itamaraty foi criada a Divisão da África que envolveria diplomatas ligados àquele continente. Também foram feitos vários relatórios sobre a região e propostas de missões diplomáticas e abertura de consulados.

De fato, foram feitas várias missões ao continente. Concretizava se em atos racionais e profissionais a política para a África, diferente do aspecto cambaleante das décadas de 40 e de 50 .

O Brasil direcionou suas energias principalmente para o Norte do continente, para a África negra atlântica, para a África do Sul e para paises africanos de língua portuguesa. Na região norte concentrou-se mais nas relações com o Egito. Na África atlântica, o país temia as relações especiais que eles possuíam com a Europa, 
preocupava o estado a concorrência com os africanos. A África negra foi a mais importante, enfatizou-se as relações bilaterais.

O Brasil aumentava as relações com os africanos visando ter um conhecimento do “outro”. O governo argumentava que só com o reconhecimento um do outro, a rivalidade econômica ficaria em segundo plano e as relações amistosas em primeiro.

As relações com a África porém, sofreram retrocessos advindos de grupos internos brasileiros. Como dito no capítulo 1, foram vários os grupos políticos que desconfiavam dessa política externa. Eles não a apoiavam por medo de perderem a aliança com os Estados Unidos. Temiam que a aproximação pudesse representar para os EUA uma guinada rumo ao socialismo.

Já para grupos de centro-esquerda a política voltada para a África era atraente e representava, a seus olhos, uma luta contra o imperialismo norte-americano. Assim a política doméstica dividia as opiniões e dificultava a ação brasileira naquela região.

Corroboravam essa dificuldade o racismo e o preconceito contra os estados africanos por parte de várias autoridades brasileiras. A falta de visão ou o olhar negativo faziam com que vários políticos não tivessem esperança no continente e assim percebendo como perda de tempo e energias preciosas a aproximação com as nações européias. Também muitos deles eram a favor do colonialismo. O fato era que enxergavam as nações européias como o mundo moderno e a África como sinônimo de atraso.

Já dissemos que Quadros tinha em mãos uma situação política interna perturbadora e isso dificultava seu governo, tanto é assim que renunciou em um ato até hoje mal explicado. Sendo assim os diversos grupos pressionavam-no para agir contra ou a favor da aproximação africana. Sem maioria no Congresso, Quadros agiu como pode e a política para aquela região não foi tão ousada como gostaria.

João Goulart, seu sucessor, manteve as políticas para a África manifestando apoio às nações dessa região. Apesar das dificuldades que também encontrou, principalmente quando iria tomar posse, Goulart foi contra os grupos de pressão, sobretudo os militares, e deu continuidade à política africana.

Para o governo Goulart, o Brasil deveria aprofundar a PEI e a política para a África. Diferente das políticas anteriores, foram muito debatidas as propostas para 
aproximar os dois com relação à descolonização. Isso ia de acordo com a inserção do país no nível internacional. As idéias sobre a África passava pelo principio da nãointervenção, autordeterminação dos povos, defesa da paz e a busca de novos mercados para seus produtos.

Já dissemos que a Política Externa Independente sofreu muitas críticas. Em sua aplicação no continente africano não foi diferente. Muitos diplomatas e políticos discordavam do plano do governo caracterizando-o como sem cabimento e impulsionador de grupos nacionalistas brasileiros. Muitos chegaram a dizer que ele direcionava o país para o socialismo.

Essas críticas se inseriam em um contexto maior, em uma briga maior, ou seja, a luta dos diversos grupos nacionais pelo controle do país. Os dois presidentes, Quadros e Goulart, passaram por dificuldades internas e que foram uma parte do processo que desencadeou o golpe de estado em 1964. A PEI fazia parte desse contexto, nela eram disputados o controle dos rumos da política externa brasileira.

Esses problemas domésticos afetaram a política externa. A política para a África sofreu muita descontinuidade. Tanto é assim que houve, de 1961 a 1964, cinco ministros da política exterior: San Tiago Dantas, Afonso Arinos de Melo Franco, Hermes Lima, Evandro Lins e Silva e, por último, Araújo Castro.

Porém, para a África negra, principalmente, houve um desenvolvimento das relações. O continente foi tratado de forma especial no período, foram criadas várias embaixadas e muitas missões diplomáticas, ainda que houvesse problemas, por exemplo, na infra-estrutura das embaixadas, o que de certa forma traz um pouco de negligencia do governo brasileiro. Mais, no geral, foi dada muita atenção aos paises africanos ${ }^{9}$.

Felizmente para as relações bilaterais houve reciprocidade por parte dos africanos. Muitos paises desse continente criaram embaixadas em Brasília, muitas vezes as primeiras na América Latina. Várias missões da África negra vieram ao Brasil.

As relações bilaterais com a África do Sul ganhavam destaque. Desde a Segunda Guerra Mundial o Brasil mantinha boas relações. Entretanto, a conotação

\footnotetext{
${ }^{9}$ SARAIVA, José Flávio S. O lugar da África - A dimensão atlântica da política externa brasileira (1946 a nossos dias). Brasília: Unb, 1996. p.72.
} 
que o país dava aos outros estados africanos entrava em conflito com aquela nação. Isso por que muitos paises africanos militaram contra o apartheid sul africano.

De fato as relações Brasil-África do Sul foram únicas no continente e ganharam matizes especiais, mas não no sentido positivo. O que quero dizer é que houve uma regressão ou um afastamento por parte do Brasil. A rede que teceia o mundo é tão complexa que pode jogar país contra país. No caso, tornava se inconciliáveis os interesses sul africanos com os dos outros estados, principalmente da África negra por conta do regime racista naquele país.

O Brasil teve que escolher entre os dois lados, pois vários paises africanos pressionavam-no para tal. O país sul americano muitas vezes se manifestou contrariamente ao regime sul africano. Sua diplomacia encarava a questão como matéria de princípio e regra do direito internacional.

O Brasil tentou adotar o terceiro caminho, ou seja, não impôs sanções contra a África do Sul, mas não apoiava oficialmente seu regime. Queria manter as relações com aquele país e tentava mostrar que diferenciava os aspectos econômicos dos morais.

Como a questão da segregação na África do Sul ganhava mais importância, sendo cada vez mais debatida e combatida, o assunto ganhou destaque na ONU. O regime do país africano se tornava um inimigo comum para o restante dos paises daquele continente, juntando-os em um objetivo comum.

Para o Brasil e para a PEI, essa situação se tornava de difícil resolução. O país não queria se afastar da África do Sul e ao mesmo tempo desejava se aproximar do restante do continente.

Na ONU, tentou conciliar os dois lados e dizia que o assunto não era de responsabilidade da Assembléia Geral. O governo brasiliense queria ampliar o comércio com o país sul africano, apesar de manter um discurso contra o regime racista. Era uma ação ambígua do governo de Quadros.

Em 1961, o Brasil enviou uma missão para aquele país com o objetivo de incrementar o comércio entre os dois. Daí se vê que, nesse caso, os objetivos da PEI entravam em choque com o de conquistar novos mercados visando a população da África do Sul. 
O Brasil reprovava o racismo, mas era contra qualquer tipo de resolução contra a África do Sul, o que poderia afetar suas relações comerciais. Na ONU, o Brasil silenciava sobre a questão, ou no máximo tentava uma abordagem conciliatória.

Isso era justificado pelo comércio entre os dois. O que o Brasil vendia para a África do Sul representava metade do comércio para todo o continente, daí a preocupação em manter as boas relações.

O Brasil utilizava o conceito de não intervenção nos assuntos internos para a África do Sul. Na ONU, muitos acusavam o país de usar esse principio de forma cínica. Era a tentativa brasileira de conciliar seus interesses naquele país, defendendo que não poderia haver embargos contra ele. Não acusaremos a proposta de única, mas de fato foi contraditória e ambígua a relação entre o Brasil, a África do Sul e os demais paises africanos.

Outro avanço em relação aos períodos anteriores foi no que diz respeito aos paises africanos de língua portuguesa. Entretanto, mesmo com todo esse avanço, o país não cortou as tendências antigas de apoio a Portugal nem deixou de ser ambígua.

O caso de Angola foi exemplar. Nos anos 60, esse país estava em grave guerra civil e isso tinha repercussões internacionais, pois também era a mais rica das colônias portuguesas no continente. Nele trabalhavam grandes empresas exploradoras de minerais e disso se aproveitava Portugal. Os impostos que elas pagavam permitiam ao estado europeu bancar a colônia e pagar os gastos da luta contra movimentos de libertação.

Foi um grande desafio para o Brasil conciliar a PEI com a tradicional aliança com Portugal, pois era esse o desejo do país. A luta de libertação em Angola começou nos anos 50 com um movimento, cujo número de intelectuais era alto, que queria o fim do colonialismo e a instalação de um governo democrático.

A guerra no país africano foi muito violenta, sendo que os portugueses tinham apoio dos Estados Unidos e foi muito discutida na ONU. Os paises africanos deram seu apoio à Angola e alguns até romperam as relações com Portugal.

Daí se vê a dificuldade do Brasil. Porém, a Política Externa Independente não distinguia uma colônia de outra, tratava todas igualmente dentro da questão da descolonização, a qual era a favor. Oficialmente, a diplomacia brasileira declarou ser 
anti-colonialista, mas que possuía compromissos com Portugal. Na ONU, quando a matéria chegou a ser discutida, o Brasil se absteve. Muitos no país denunciaram a contradição e a falta de medidas firmes do governo brasileiro.

No Congresso Nacional, a posição brasileira foi criticada por aqueles que eram a favor dos preceitos da PEI, mas recebeu votos a favor daqueles que eram anticomunistas e que viam nos movimentos de libertação africanos futuros governos socialistas. Mas em sua maioria, os políticos criticavam a ambigüidade da política externa brasileira.

Na ONU, o Brasil tentava conciliar o inconciliável, queria chegar a um acordo entre Portugal e Angola. Seus discursos eram nessa tendência, mas quem analisar seus pormenores não deixará de enxergar o explícito apoio a Portugal. Chegava ao ponto de clamar àquele país que chefiasse a libertação de Angola para que este país fosse amigo da nação européia e do Brasil.

O bloco dos paises africanos, exceto a África do Sul, votou uma resolução de apoio à Angola e que desejava a passagem gradual do poder de portugueses para angolanos. O Brasil votou conjuntamente. Em outras palavras, dava apoio aos dois lados, sendo aspirações totalmente opostas.

Não retirando seu apoio a Portugal, o Brasil afirmava também que era chegada a hora da independência das nações africanas. Isso gerou enorme descontentamento de grupos de portugueses e descendentes instalados no país. A pressão foi grande, mas o ministro das relações exteriores da época, San Tiago Dantas, não voltou atrás com sua palavra.

Defendia que o apoio às nações africanas era parte da inserção internacional do país e que o Brasil ganhava a chance de aumentar sua participação e influência nas questões mundiais além de buscar novos mercados.

O discurso brasileiro era de apoio à libertação dos africanos, mas sem entrar em confronto com Portugal. Daí chamar o país europeu para liderar a independência angolana. O que não excluía a ambigüidade da posição brasileira, tanto é assim que o país se absteve em votações na ONU sobre a independência de Angola.

A questão vai mais além da percepção das autoridades brasileiras. Como dito nesse capítulo, a política externa foi muito influenciada pelo que ocorria internamente. A posição oficial do governo brasileiro sobre a luta entre portugueses e 
angolanos sofreu a pressão de grupos ligados a Portugal, grupos nacionalistas, partidos políticos, da mídia e de outros. Com certeza não foi fácil escolher o melhor caminho, ou melhor, seguir o rumo já traçado pelas diretrizes da PEI.

Essa é uma questão importante sobre a Política Externa Independente, a de que a perturbação da ordem e os conflitos políticos, por exemplo a difícil passagem do governo de Quadros para o de Goulart descrito no primeiro capítulo, decidiam muitas vezes o caminho da política externa. Corrobora esse argumento o fato de que em um curto espaço de tempo ter havido tantas trocas de ministros, incluindo os de relações exteriores.

Também a diplomacia portuguesa foi muito eficiente nessa questão. Conseguiu influenciar as decisões brasileiras na matéria e nas votações na ONU. Os Estados Unidos, com sua política de segurança, tentaram envolver o Brasil na manutenção da África para o bloco capitalista. Está claro que o país norte americano não apoiaria um regime com tendências comunistas. Isso além do que as relações entre ele e o Brasil estarem em conflito. E havia o receio brasileiro de que, após a independência, a Angola e outras colônias de Portugal se afastassem da cultura portuguesa e consequentemente deixassem de se assemelhar ao Brasil.

A política para a África teve uma conotação ideológica ou cultural, a saber, a identidade e a história do Brasil que passava por aquele continente. Isso foi construído conscientemente pelo governo brasileiro.

Imaginar características comuns entre os dois deveria facilitar a aproximação e incrementar a relação. Muito se falava no país em "ponte” e "porta de acesso” ao continente. A história foi usada para enfatizar semelhanças e em vários discursos de Quadros e Goulart diziam que os novos estados deveriam mirar no Brasil o bom futuro deles.

Pelo lado africano, muitos paises se juntaram a essas idéias, aderindo à fórmula brasileira, porém houve alguns que olhavam desconfiados para essas palavras.

Para concretizar, mostrar em atos a força dessas idéias, foi nomeado um jornalista negro, Raymundo de Souza Dantas, para embaixador em Gana. Era parte da política de aproximação, uma forma de Quadros mostrar aos africanos que estava falando sério. 
Esse ato também serviu para o governo se aproximar dos brasileiros negros. Assim mais uma vez houve uma ligação entre as políticas interna e externa. Foram feitas muitas ações que enfatizavam a cultura negra por parte do Brasil na África e oferecidas bolsas de estudo para estudantes africanos.

Isso tudo para mostrar que o Brasil, que teve uma história semelhante à África, com uma cultura e identidade correspondente àquele continente, passou por um processo de industrialização e conseguiu certo desenvolvimento. Em outras palavras, o governo brasileiro queria que as nações africanas se aproximassem do país, tomando o como um modelo a ser seguido e como um líder que guiá-los-ia rumo ao desenvolvimento. No Brasil esse discurso teve amplo apoio dos intelectuais e da academia. O Itamaraty foi influenciado por eles e compartilhou dessas idéias.

Concluindo, a PEI, em sua aplicação à África, foi contra o colonialismo, mesmo de forma ambígua, principalmente com as colônias portuguesas e tentou se aproximar dos paises daquele continente.

Por décadas, essa região foi esquecida e deixada de lado pelos brasileiros. A delegação brasileira nos anos da PEI defendeu os interesses africanos tentando conciliar metrópoles e colônias, mas em geral era a favor da independência das últimas. 


\section{CONCLUSÃO}

Essa monografia analisou como foram as relações do Brasil com a África durante a Política Externa Independente. Foram estudadas as linhas gerais da PEI, a descolonização africana e a aplicação no continente africano dessa política externa.

A PEI foi uma inovação em relação às políticas anteriores do Brasil. Porém, teve muitas críticas e não raras vezes recebeu o título de política comunista. Por outro lado, foi bem recebida por diversos grupos nacionais e estrangeiros.

Essa política teve precedentes na história brasileira. Momentos de maior autonomia na história do Brasil influenciaram a formação dessa política pelos governantes da época. Foi marcante o fato dela ter sido concebida no governo do presidente Jânio Quadros, pois seu caráter autônomo se deu em decorrência dos aspectos mais independentes da política desse presidente e das próprias qualidades pessoais de Quadros.

Contudo, a formação dessa política não se deu independente do que ocorria no mundo. Este vivia sobre o julgo da Guerra Fria, o Brasil era pressionado e passava por um período difícil. Foi uma escolha difícil, mas estava de acordo com a situação nacional.

O Brasil nunca quis sair do mundo ocidental, escolheu procurar por maior independência para conseguir se desenvolver. Daí que as críticas sobre essa política ser socialista não encontraram respaldo no contexto mundial.

Juntas a essas transformações estavam as mudanças pelas quais a África passava. A descolonização e a ascensão de novas nações africanas modificaram profundamente o cenário mundial. As duas superpotências, a URSS e os EUA, tiveram que mudar suas políticas e, de certa forma, se adaptar às crescentes imposições que o mundo sofria.

De fato a Política Externa Independente somente conseguiu se manter por que encontrou respaldo no cenário mundial. As novas linhas da política externa, que visavam uma participação mais ativa do Brasil no cenário global, se juntaram às aspirações de outros estados nacionais. 
O caso da África foi bem elucidativo. As nações africanas queriam apoio para suas independências, o que não encontraram nem em suas metrópoles nem nas duas superpotências. Os moldes independentes da PEI, combinados com a procura por novos mercados, encontraram nos africanos uma base de operações. Houve, claro, problemas com algumas nações, principalmente com a África do Sul e com as colônias de Portugal, mas eles decorreram de motivos econômicos, no primeiro caso, e em uma percepção conturbada, no segundo.

Na PEI, as relações do Brasil com a África ganharam matizes antes nunca tidos. Ocorreu a aproximação de interesses dos dois, um foi importante para o outro, criou se uma verdadeira identidade entre os dois, sendo que o Brasil construiu uma visão e uma cultura para a África.

Entretanto, a política externa não se dissociou da interna. Como dito, o Brasil passava por problemas sérios. A política doméstica influenciou a aplicação da PEI e a levou ao seu fim.

A Política Externa Independente teve seu fim com o golpe militar de 1964. Entretanto, seus ideais encontram continuidade na posterioridade. Sua contribuição para a história do Brasil foi rica e importante. Mesmo que vários governos posteriores tivessem adotado políticas externas retrógradas, como foi o caso, isso não apaga os resultados da PEI.

Ela abriu um novo leque de possibilidades para o Brasil. Recentemente o presidente Luis Inácio Lula da Silva fez várias viagens para paises africanos e reafirmou a importância da África na história do país. Esse discurso não foi criado por ele, teve origem em políticas externas passadas que enriqueceram os objetivos do estado. Políticas nas quais a Política Externa Independente faz parte. 


\section{REFERÊNCIA BIBLIOGRÁFICA}

ARAGÓN, Daniel Patrick. Brazilian Foreign Policy in África, 1961-1976. 2001. 339p. Tese (Doutorado) - Auburn University. Alabama, 2001.

CERVO, Amado Luís \& BUENO, Clodoaldo.História da Política exterior do Brasil. 2a a edição. Brasília: Editora da UnB, 2003.

NUNES, Aurimar Jacobino de Barros. Política Externa Independente (1961-1964): Considerações sobre o Homem de Estado. 1999. 212p. Dissertação (Mestrado) Universidade de Brasília. Brasília, 1999.

PENNA FILHO, Pio. O Brasil e a descolonização da África nos anos Kubitschek (1956-1961): Ensaio de mudança. 1994. 176p. Dissertação (Mestrado) Universidade de Brasília. Brasília, 1994.

SARAIVA, José Flávio S. O lugar da África - A dimensão atlântica da política externa brasileira (1946 a nossos dias). Brasília: Unb, 1996.

SELCHER, Wayne Alan. The Afro-Adian dimension of Brazilian Foreign Policy, 1956-1968. 1970. 416p. Tese (Doutorado) - The University of Florida. Florida, 1970 .

SIBECK, Gary Page. Brazil’s Independent Foreign Policy. 1971. 303p. Tese (Doutorado) - University of Southern California. California, 1971.

SOUZA, Creomar Lima Carvalho de. Do conservadorismo ao Desinteresse - Três estudos de caso sobre o posicionamento brasileiro frente à descolonização Afroasiática (1946-1961). 2005. 130p. Dissertação (Mestrado) - Universidade de Brasília. Brasília, 2005.

STORRS, Keith Larry. Brazil's Independent Foreign Policy, 1961-1964:

Background, Tenets, Linkage to domestic politics, and aftermath. 1973. 498p.

Tese (Doutorado) - Cornell University. New York, 1973.

VIZENTINI, Paulo G. Fagundes. O nacionalismo desenvolvimentista e a política externa independente (1951-1964). Revista Brasileira de Política Internacional, v.1, n.37, p.24-36, 1994. 